\title{
The Play Your Process Method for Business Process-Based Digital Game Design
}

\author{
Tadeu Moreira de Classe ${ }^{1,2}$, Renata Mendes de Araujo ${ }^{2}$, Geraldo Bonorino \\ Xexéo $^{2,3}$, Sean Wolfgand Matsui Siqueira ${ }^{1}$ \\ ${ }^{l}$ Programa de Pós Graduação em Informática - Universidade Federal do Estado do Rio \\ de Janeiro (PPGI-UNIRIO) \\ \{tadeu.classe,sean\}@uniriotec.br \\ ${ }^{2}$ Laboratório de Ludologia, Engenharia e Simulação (LUDES), Proframa de Engenharia \\ de Sistemas Computacionais (PESC/COPPE), Universidade Federal do Rio de Janeiro \\ (UFRJ) \\ rma.renata.araujo@gmail.com \\ ${ }^{3}$ Departamento de Ciência da Computação (DCC/IM), Universidade Federal do Rio de \\ Janeiro (UFRJ) \\ xexe@cos.ufrj.br
}

\begin{abstract}
Serious games are useful tools to engage, educate and train individuals in many areas. They are also suitable for the business processes management area where it is expected that business process-based digital games can bring together players (process actors) to better understand and learn organizational business processes. Building business process-based digital games is a challenging task due to the fact that game design must be performed in a systematically way, integrated into the business process management cycle. Indeed, game designers usually do not have business process modeling skills and instructions on how to represent business process elements in the game context; also, process analysts do not have enough game design skills. This research article presents the Play Your Process (PYP) method, a digital game design method for the development of games which aim to provide business process understanding to players without forgetting the fun. In that sense, the method systematizes the design of these games, decreasing interdisciplinarity in the game project through the use of business process models as input, by mapping it into game design elements and proposing how to evaluate the games. In order to validate the PYP, a set of games was built and evaluated with designers, process executors and players. The games designed using PYP showed good quality, and players' understanding regarding the process increased after they had played the game, although there is still room for fun and entertainment improvement.
\end{abstract}

Keywords: Digital Game Design; Business Process, Business Process Model; Game Design Method; Business process-based digital games; Play Your Process;

\section{Introduction}

This research article presents a game design method called Play Your Process (PYP) for creating serious games based on business processes. Those business process-based digital 
games provide process understanding to players, as well as promote a reflection on process challenges and difficulties.

Games are innovative tools known for their huge potential to support the learning process [1], they are not made only to entertain, but also, to teach or to bring behavior changes, which could benefit people in the real world [6]. Serious games (SG) are considered useful tools to educate and engage their users in many areas [3][4][5], and they bring new opportunities in a large number of domain fields, however, they bring challenges to their design and adoption in new contexts.

This research work focuses on organizations as the context for designing SG, specifically on how SG can improve business process execution and management. Organizations have been adopting business process management (BPM) approaches in order to cope with the need for continuous improvement, achieving higher performance indicators and process' customization to clients. The BPM cycle comprises continuous steps of process redesign, in which each redesigned process must be adopted into the organization life, especially to process executors and clients [6]. We believe that games could be an approach to support process learning and understanding in organizations; they can be useful not only to explain how a process must be performed, but, also, to teach process values and organizational challenges.

Designing business process-based digital games is a singular task and must be done in a systematic way. If an organization needs to design a game for each process redesign using traditional approaches, it will be expensive in terms of time and money. A method to design these business process-based digital games is presented in this article. The method should use a business process model as the primal source of information to perform each game design steps, supporting game designers to systematically build SG according to the business process. The resulting game must be framed into the business process objectives, rules, restrictions, and values to ensure that players will learn the business process accordingly.

Therefore, the research challenge addressed in this article is:

\section{How to design a digital game that helps players understand and learn about the underlying business process?}

To design business process-based digital games is necessary to think how the process information will be translated to the game language, without letting the game be only a process simulator. A business process, by nature, is deterministic, its process models are static representations of how the process work. Translate it to game elements is a challenging task because there is the need to balance process learning and fun process understanding by the players.

This research was carried out using the Design Science Research Methodology (DSRM), which approaches the creation of an artifact based on theoretical conjectures and design requirements in order to solve a problem, contributing both to design and scientific knowledge [7]. The artifact this research proposes is a game design method based on business processes models to solve the challenge previously presented. The theoretical bases are game design methods, BPM and Social BPM. In this article, we explain how to perform each design step and their results. DSRM predicts that design science research must demonstrate artifact use; thus, a case study on using the method to design a serious game from a real business process, including player evaluation is presented.

This article is organized as follows: Section 2 presents the research conceptual background. Section 3 presents related work. Section 4 describes the Play Your Process method - the game design method based on business processes. Section 5 shows game examples obtained by the method application. Section 6 presents a case study of the use of the game design method based on a real business process. Section 7 discusses research limitations. Finally, section 8 highlights conclusions and future work. 


\section{Background}

This section addresses the concepts used in this research, regarding game design engineering, business process management and Social BPM.

\subsection{Game Design Engineering}

Professional game design is an expensive activity, requiring a multidisciplinary effort to deal with both technical and aesthetic aspects [8]. Traditional game design approaches [9][10] are often based on software engineering processes - concept, pre-production, prototyping, production, and assessment. According to different authors [11][12], as there are different kinds of software which need different ways of development, there are also different genres of digital games (adventure, action, sports, simulation) which need different design methods. Design techniques to create an action game are different from that of a puzzle game, and it is hard to cover all game differences in a unique method [15]. Some methods have gained visibility, due to lack of consensus about how to do so, such as the game development with Scrum proposal, by Keith [13].

Game design engineering is not only computer science or software engineering, but also rather a multidisciplinary subject, including arts, math, psychology, etc. Differently from software engineering, in game design engineering, the success of a game is not only guaranteed by a functional software. Entertainment must be present, even in a serious game, because player's satisfaction and pleasure are the most important success metrics [14].

Game engineering aims to join techniques, steps, tools and knowledge to design different kinds of games for different contexts, organizing and suggesting approaches, methods, practices and tools to help game development [15].

\subsection{Business Process Management (BPM)}

Business processes are a set of events, activities, and decisions performed by humans or systems using resources to reach certain goals to generate an artifact or deliver a service to customers [6]. Business Process Management (BPM) is known as an approach that analyses how the work is performed in the organizational context, improving business performance [16]. BPM is associated to steps as i) process identification/discovery: eliciting process execution by observation, interviews, and documentation; ii) process modeling: creating a graphical representation and formal description of the process; iii) process analysis: identifying bottlenecks and opportunities for process improvement; iv) process redesign: redesigning the process to overcome its problems or improve its performance; v) process implementation: deploying the redesigned process in the organization; and vi) process monitoring: following-up of the process performance based on key performance indicators [6]. According to Sharp \& McDermott [17], the success of any process-oriented initiative depends on the process understanding step because it precedes process execution and improvement.

Process modeling is characterized by representation and description of a process in terms of goals, actors, activities, flows, rules, resources, products, etc. [6]. A process model is created to simplify process understanding, related to process execution, providing a general idea about process rules and organizational inter-relationship [18]. There are many process modeling languages (BPMN, EPC, UML, etc.), besides their metamodels (BPDM, XPDL, etc.) [19] which give meaning to process elements. In narrative terms, a process can be described by documentation and stories that provide details on how a process is performed. Process modeling is the basis for designing business process-based digital games; the designer must know process specification/modeling, to enable him/her to represent it in a 
pag. 30

game context, avoiding transmitting the process wrongly, or with non-true information. Our method decrease the necessity in being a process modeling expert. Therefore, we argue that process models provide elements which can be directly mapped into game design, as we will show in PYP method.

\subsection{Social BPM}

According to Schönthaler et al. [20], Social BPM is based on the idea that BPM is under the responsibility of the entire business community, comprising all people involved with the business (internal and external). Social BPM environments should provide the possibility of connecting relevant stakeholders, allowing them to discuss and improve organizational processes [21][22]. The benefits of Social BPM can be huge when knowledge and creativity over business process are shared with those involved with the process [23]. This allows for the discovery of process implicit knowledge, organizational transparency, and distributed decision-making [24][25][26].

Despite the benefits associated with Social BPM, a number of researchers, such as Afandi [27], Pflanzl and Vossen [23] and Rangiha [25], have discussed that the sharing information and points of view from external participants, and participants' engagement are challenging. As participation of those external people is not an easy task, it is necessary to find new ways to increase interaction and bring them closer. In this research, we argue that Business process-based digital games can help address this challenge because games may bring people and organizations closer through process understanding.

Regarding the challenge of how to improve process understanding, an attractive way of approaching it can be through digital games, specifically by serious games. They can enable who plays the game to understand how the services are provided and performed by organizations, having a glimpse of process particularities and difficulties [28]. Thus, the games can be one alternative to give support to the Social BPM, approaching the challenge of process understanding by the actors.

\section{Related Work}

This section presents related work concerning serious games design. Moreover, a literature review is presented about "how/where" the business processes have been used in game design methods.

\subsection{Serious Game Design}

There are many different approaches for serious game design. Very often, these serious games design methods suggests guidelines and techniques, but lack practical demonstrations [29].

One of these methods is a MDA variation for serious games, the DPE framework [30] which relates Design, Play, and Experience dimensions with learning, narratives, gameplay, and player experience elements. Another example is the research by Siriaraya et al. [29], which have proposed a complete game design process for persuasive games starting from the definition of the desired effect (game purpose), for game effectiveness measure [31].

According to Kelly [32], in order to design serious games, the game design team must learn about the knowledge domain where the game will be played. Artists, designers and programmers must all understand the domain context in order to communicate it accordingly in the game.

When considering game design based on business process, it is necessary to think about process domain and elements, which must be represented in the game context [28], such as process activities, goals, problems, rules, actors and roles [33][34]. Those "business process-based digital games" must enact a business process flow with fidelity for the 
players' understanding; therefore, game designers need to understand all process aspects to deliver a game with the right process information.

\subsection{From Business Process to Game Design}

Classe and Araujo [35] have performed a literature review to identify research work associating digital game design and BPM. It was found that research literature is focused on the use of digital games for process modeling learning and organizational training. Only Solís-Martines et al. [36] brought attention to the proposal of a new notation based on BPMN (Business Process Modeling and Notation) to define logical features in digital games. However, the proposal doesn't focused in creating games to business process.

Pflanzl et al. [37] proposed a digital game for citizen's understanding of the Brazilian retirement process. They described possible steps for the game design, from its conception to its evaluation, but the proposal was only theoretical. Classe et al. [33] conducted an exploratory study about digital game design based on public services processes, presenting an initial view of a digital game based on public processes.

Considering market solutions, we have found the simulator game called IBM's INNOV8 (2007), where players can observe, in real time, process changes in the organization, and should interfere in the task to try to increase process performance.

Classe et al. [34][38] show a proposal to map process model elements into game design elements, creating a preliminary view of process representation in the game. In 2017, Classe et al. [39] performed a new literature review that aimed to find research work combining BPM and game design. Few papers were found in that research, including the proposal to use BPMN as a pattern to define game features and logic [36]; another paper was the approach for organizing a game design process into a BPMN model [40].

\section{A Method for Designing Business Process-Based Games}

This section presents our proposal of the Play Your Process (PYP) method which is a method for designing business process-based digital games. The main novelty and contribution of the method is, based on the game engineering concepts, to organize the business process-based digital game design process, guiding the game designer through the steps of engineering this kind of serious games from concept to evaluation based on business process information. The whole idea is to extract from the organization process model and context, all the information needed to design the game: elements, rules, values, challenges, environment etc.

An overall description of the method steps is depicted in Figure 1. The PYP method uses as the primal source, the organization processes and their models. Game designers need to understand the process (context analysis), to build a map between process elements and game design elements (process-game mapping), thereby building the game design document (GDD). The mapping step is supported by a tool especially designed for this purpose called "Process Model Game Design" (ProModGD) [34] which supports the creation of mapping sheets and an initial version of the GDD. From the GDD, it is possible to progress to the game project (the designer uses his/her creativity to create an enjoyable game, using his/her experience, thereby creating new mechanics and aesthetics), prototyping and development, and evaluation [28]. When the results of the evaluation considers the game satisfactory, the game is packed and published (game publishing).

The details of each step of the PYP method are presented in the following sections, illustrated with the design of the serious game Desaparecidos (Missing People, in English).

\subsection{Context Analysis}


pag. 32

The game design method receives as its input the processes models for which the organization wishes to create a digital game. The business process model must be understood by game designers, especially qualitative information about the process (context, values, social issues, etc.) allowing game designers to think about game environment, character behaviors, and other game design information. This step aims to promote discussion and to organize information about the business process context, how it is performed in the organization and the experience of actors/clients about the process as well as their perception of the process relevance, performance, and quality are, in order to provide useful information to enable the game design team to create the main concepts for the game. All information obtained in this step must be recorded in a final document (context document) which is useful for game project contextualization.

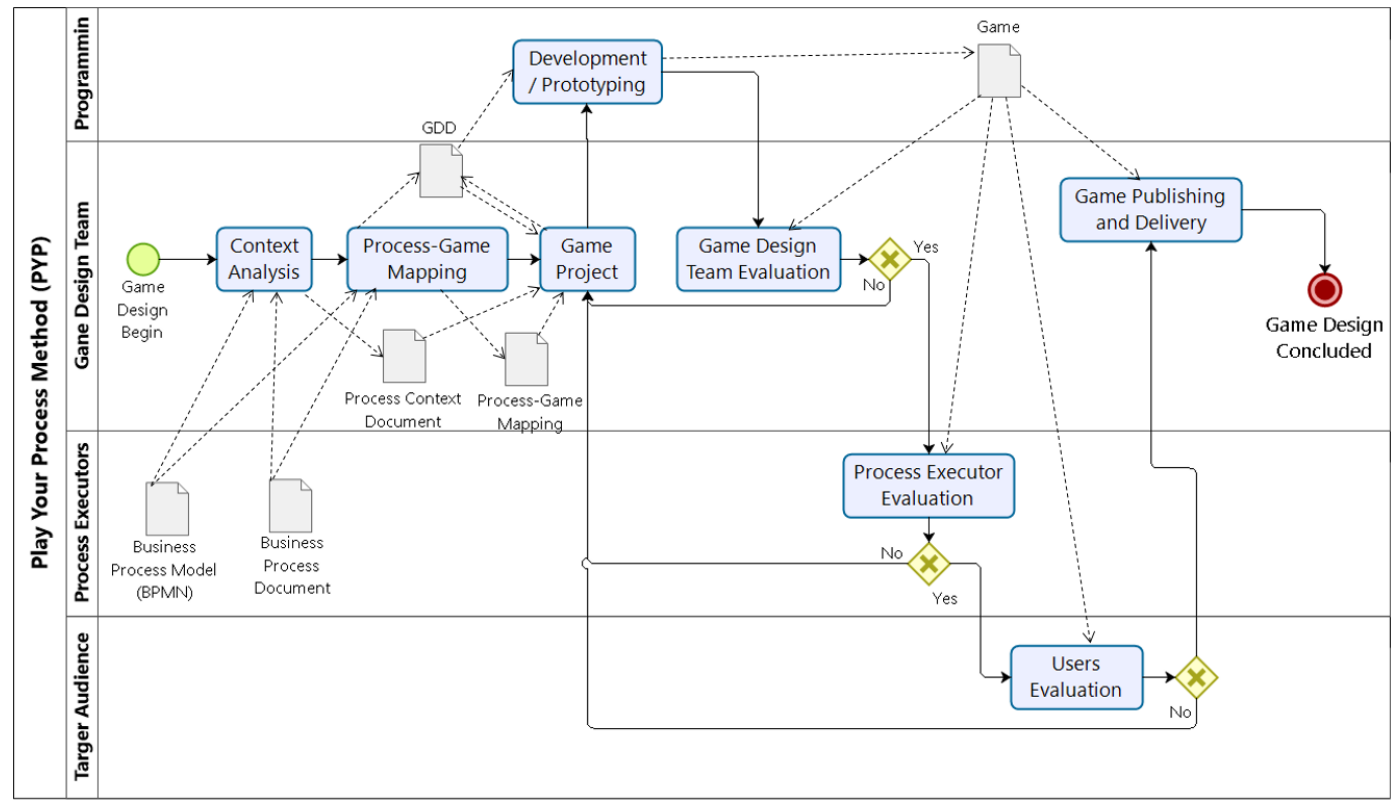

Figure 1. The PYP Method Game Design Steps.

We have proposed a set of questions grouped into three categories: i) organizational context $_{s}$ in order to understand organizational settings (organizational values and mission; organizational strategy; customer selection; market branch, etc.); ii) process context, in order to understand process details (clients profile motivation; goals; challenges; main activities; roles and actors; last changes in process flow, etc.); and iii); user context, in order to investigate how the user experiences the process (feelings and thoughts about the process; main difficulties and frustrations; process transparency, etc.).

Different approaches could be used to acquire this kind of process information. Sharp et al. [17] and Dumas et al. [6] suggest expert sessions to understand more about the organizational context. During these expert sessions, it is possible to use questionnaires, interviews, storyboards, etc., as techniques to acquire and store information. Moreover, it is possible to analyze organizational documents such as forms, reports and others.

\subsection{Desaparecidos - Context Analysis}

The scenario is the Missing Person Discovery process, a process performed by the Police Department in Rio de Janeiro, Brazil to look for missing person in the state. According to the Public Security Institute of the state of Rio de Janeiro (ISP/RJ), about 33 thousand persons were declared as missing between 2002 and 2017. As the service and its steps are unknown by the citizens [41], which leads to confusion and disappointment in service provision, the Police Department seeks to improve citizens' knowledge about it.

Through meetings and interviews with the police representatives at the police Department (DDPA, in Portuguese) (expert sessions), it was possible to identify the civil 
police organizational values (ethics, discipline, hierarchy, commitment, human rights, transparency, focus on the citizen). Additionally, the DDPA representatives also informed us that citizens do not know which information is necessary to report when someone disappears, and that many of them are afraid of reporting a missing person case because they usually fear the police, which is a great problem in the identification process.

With all the information obtained in this phase, it was possible to develop the context document, answering important questions, such as: What is the process and why it exists? The process was created to give the citizens of Rio de Janeiro an effective channel to report, investigate and solve missing person cases. Who delivers the process? The missing person police department. Who are the customers of the process? Citizens who live in the State of Rio de Janeiro. How is the process performed? Narratives examples and process modeling acquired during meetings with DDPA produced the BPMN model depicted in Figure 2.

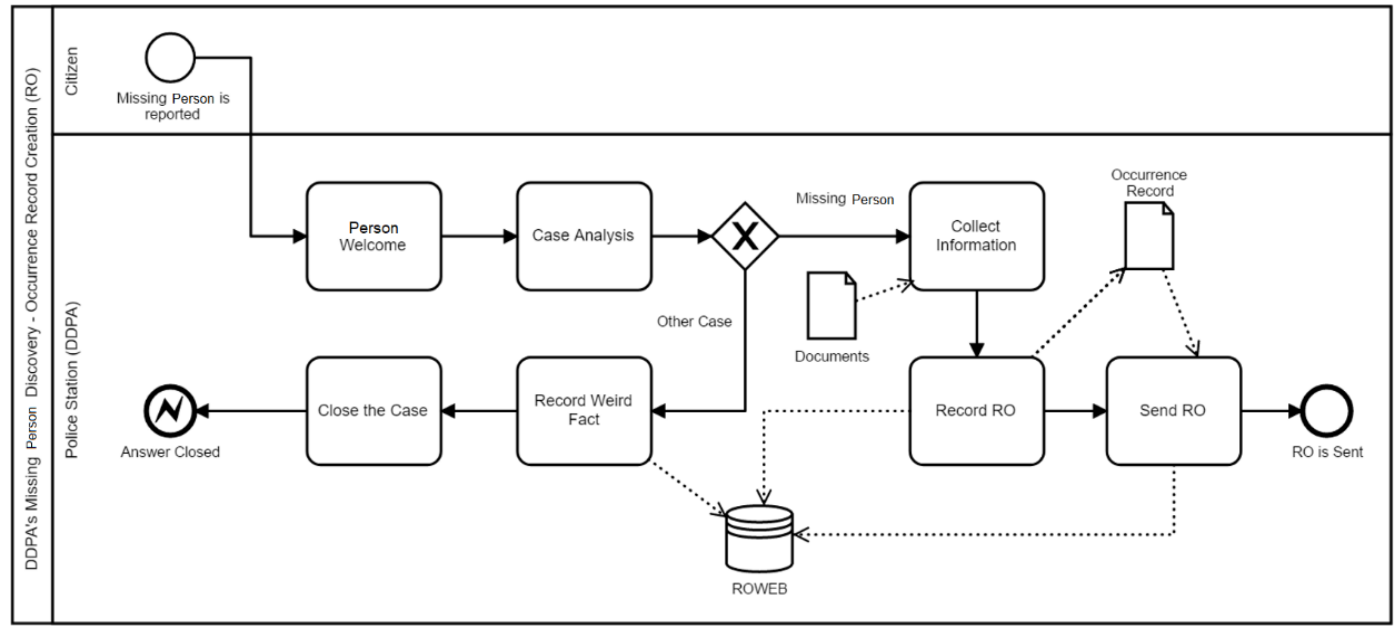

Figure 2. Missing Person (Occurrence Record) Process.

\subsection{Process Model to Game Design}

It is argued that it is possible to define game elements built upon process model elements and documentation to build compliant business process-based digital games. For instance, game stories can be built upon process instances, game tasks can be associated with process activities, game characters with process actors, game rules based on process rules and decisions and so on. Therefore, the PYP method suggests a step to help game element identification from process elements.

We studied process modeling languages and their meta-models (XPDL, BPDM, BPMN), and we have chosen BPMN as the main modeling language to be addressed (due to its broad use in the market) and built a corresponding map between each BPMN element to adventure game elements.

This genre was selected, based on its similarities with the whole idea of business process modeled in BPMN (flow of activities to be performed in order to achieve a specific goal). In an adventure game, generally, a character (hero or player) is presented with a problem and has the goal to solve it; in her path, she needs to perform many tasks in each of them; she consumes resources to create items; at the end, she reaches her goals and wins the game. Zahari et al. [42] have proposed common elements of adventure games, and meanings and concepts for each of them: players, tasks, missions, rules, world, characters, environments, etc.

The element mapping steps are based on the following premise: Starting from a business process model (considering graphics and document models) and a game genre, it is possible to associate elements (process model elements and game elements) by their meaning, performing the match between both to build an element mapping document. A 
GDD is generated from the element mapping document, which helps game designers in the design of business process-based digital games. (Figure 3 ).

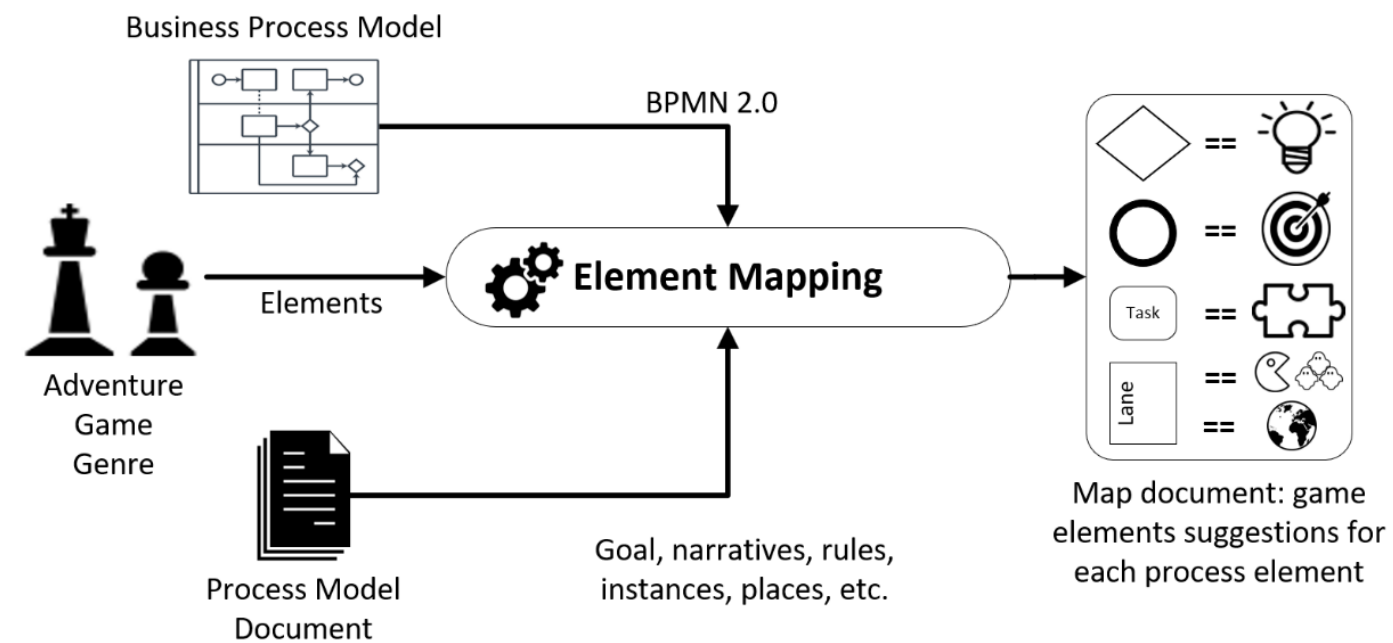

Figure 3. Element mapping method.

In order to perform this step, conceptual mapping among process elements and game design genre elements was defined. Conceptual mapping shows how each BPMN element in the process model can be associated to a specific game element (Table 1) [38], considering adventure games elements. This conceptual mapping was implemented in the ProModGD supporting tool [34].

Similarly, a business process aims to solve problems in order to reach an organizational goal; it is necessary to perform tasks, which consume resources and create outcomes; and in the end, a product or service is delivered, thereby reaching process goal. Thus, a business process can be mapped to an adventure game.

Table 1. Mapping guidelines between process model elements and adventure game elements.

\begin{tabular}{|c|c|c|c|c|}
\hline $\begin{array}{l}\text { Process Model } \\
\text { Element }\end{array}$ & BPMN Symbol & Element Meaning & $\begin{array}{l}\text { Adventure } \\
\text { Elements }\end{array}$ & Game Meaning \\
\hline \multirow{3}{*}{$\begin{array}{l}\text { Lanes } \\
\text { (Participants) }\end{array}$} & \multirow{3}{*}{$\int^{\frac{2}{2}}$} & \multirow{3}{*}{$\begin{array}{l}\text { Responsible party } \\
\text { (person or } \\
\text { department) for task } \\
\text { execution and process } \\
\text { activities. }\end{array}$} & Players & $\begin{array}{l}\text { Players perform tasks and activities } \\
\text { in the game world. }\end{array}$ \\
\hline & & & Characters & $\begin{array}{l}\text { Characters (NPC) are people, } \\
\text { animals,or things that can interact } \\
\text { with the player. They can be related } \\
\text { to rules and activities in the game } \\
\text { world. }\end{array}$ \\
\hline & & & $\begin{array}{l}\text { Places - } \\
\text { Game } \\
\text { World }\end{array}$ & $\begin{array}{l}\text { The game environment It comprises } \\
\text { places, world, buildings, islands, } \\
\text { etc. and help to gameflow. }\end{array}$ \\
\hline Initial Events & & $\begin{array}{l}\text { Event that starts a } \\
\text { process or part of a } \\
\text { process. }\end{array}$ & $\begin{array}{l}\text { Plot: Initial } \\
\text { Event }\end{array}$ & $\begin{array}{l}\text { It is an event that starts the story. It } \\
\text { motivates the facts and it is the } \\
\text { reason for the player to execute the } \\
\text { activities. }\end{array}$ \\
\hline \multirow{2}{*}{ Final Events } & & \multirow{2}{*}{$\begin{array}{l}\text { Events that finish a } \\
\text { process or part of a } \\
\text { process. }\end{array}$} & $\begin{array}{l}\text { Plot: } \\
\text { Solution }\end{array}$ & $\begin{array}{l}\text { It is the goal of the game. The right } \\
\text { (or expected) result of all player } \\
\text { actions; success result. }\end{array}$ \\
\hline & & & Plot: Fails & $\begin{array}{l}\text { They are all failure situations. Each } \\
\text { failure related to game over, life }\end{array}$ \\
\hline
\end{tabular}




\begin{tabular}{|c|c|c|c|c|}
\hline & & & & $\begin{array}{l}\text { decrease or the feedback of } \\
\text { something wrong in the game. }\end{array}$ \\
\hline $\begin{array}{l}\text { Gateways } \\
\text { (Condition) }\end{array}$ & & $\begin{array}{l}\text { It controls the task } \\
\text { execution flow, } \\
\text { defines a sequence in } \\
\text { an exclusive way. }\end{array}$ & Rules & $\begin{array}{l}\text { The rules govern player mechanics, } \\
\text { actions and functions, they act } \\
\text { under items and turn around the } \\
\text { game world. Rules affect the game } \\
\text { flow. }\end{array}$ \\
\hline \multirow{2}{*}{$\begin{array}{l}\begin{array}{l}\text { Instances } \\
\text { (Process } \\
\text { Courses) }\end{array} \\
\text { *From the } \\
\text { process model } \\
\text { document }\end{array}$} & \multirow[b]{2}{*}{-} & \multirow{2}{*}{$\begin{array}{l}\text { Example of ordered } \\
\text { task succession. They } \\
\text { describe an example } \\
\text { of how process is } \\
\text { performed. }\end{array}$} & Story & $\begin{array}{l}\text { The story is a sequence of related } \\
\text { activities with tasks, characters } \\
\text { roles and objectives which must be } \\
\text { performed during the game. }\end{array}$ \\
\hline & & & Narrative & $\begin{array}{l}\text { The narrative is the way how the } \\
\text { story is told, it is how the story is } \\
\text { represented, the details, how the } \\
\text { characters, tasks and plots are } \\
\text { related so as to tell the story. }\end{array}$ \\
\hline \multirow{2}{*}{$\begin{array}{l}\text { Activities (Task } \\
\text { and Sub-process) }\end{array}$} & \multirow{2}{*}{ Task } & \multirow{2}{*}{$\begin{array}{l}\text { Work or tasks to be } \\
\text { performed in process } \\
\text { context. }\end{array}$} & Tasks & $\begin{array}{l}\text { Tasks are designations, actions to } \\
\text { be performed by characters in the } \\
\text { game world. }\end{array}$ \\
\hline & & & Feedback & $\begin{array}{l}\text { All information, items, dialogs, and } \\
\text { results gained from task execution. }\end{array}$ \\
\hline \multirow{2}{*}{$\begin{array}{l}\text { Flows } \\
\text { (sequences, } \\
\text { messages, } \\
\text { information) }\end{array}$} & & \multirow{2}{*}{$\begin{array}{l}\text { Represents the } \\
\text { temporal order in } \\
\text { which actions happen }\end{array}$} & Interaction & $\begin{array}{l}\text { Interactions are behaviors or the } \\
\text { result from two or more game } \\
\text { objects (characters, items, tasks), in } \\
\text { which one affects the other. }\end{array}$ \\
\hline & & & Rules & $\begin{array}{l}\text { Rules govern player mechanics, } \\
\text { actions and functions,. }\end{array}$ \\
\hline \multirow{2}{*}{ Resources } & \multirow{2}{*}{$\cong$} & \multirow{2}{*}{$\begin{array}{l}\text { Represents data, } \\
\text { systems, files, forms, } \\
\text { etc. }\end{array}$} & Items & $\begin{array}{l}\text { The player usually collects and uses } \\
\text { objects (items) to solve problems } \\
\text { (tasks, rules, goals). }\end{array}$ \\
\hline & & & $\begin{array}{l}\text { Feedback } \\
\text { (Rewards) }\end{array}$ & $\begin{array}{l}\text { They are motivation, reward, items } \\
\text { to reach some objective, can also be } \\
\text { game points. }\end{array}$ \\
\hline \multicolumn{5}{|l|}{ Goals } \\
\hline $\begin{array}{l}\text { *From the } \\
\text { process model } \\
\text { document }\end{array}$ & - & $\begin{array}{l}\text { Goal and motivations } \\
\text { to perform the } \\
\text { process. }\end{array}$ & Goal & $\begin{array}{l}\text { The goal comprises the target } \\
\text { situations that should be reached by } \\
\text { the player. }\end{array}$ \\
\hline
\end{tabular}

In a business process-based digital game, the game designer must think on how to relate all the process elements in the game environment. The mapping step makes it easier because it saves the game designer time, which, previously, should be used to understanding process elements.

Two documents are generated as output of this step: the mapping document and the game design document (GDD) based on element mapping. The GDD groups the mapping document into sections such as game context, tasks, mechanics, interactions, events, and others. The GDD provides an initial view of game requirements, which might be updated in the next steps.

\subsection{Desaparecidos-Process-game Mapping}

Using the BPMN model of the Missing Person process (Figure 2), the process-game mapping step was performed, resulting in the mapping presented in Table 2. 
Table 2. Game design elements mapped from BPMN process model to Desaparecidos.

\begin{tabular}{|c|c|c|c|c|}
\hline $\begin{array}{l}\text { Process Model } \\
\text { Element }\end{array}$ & BPMN Symbol & Element Meaning & $\begin{array}{l}\text { Adventure } \\
\text { Elements }\end{array}$ & Game Design Elements Mapping \\
\hline \multirow{3}{*}{$\begin{array}{l}\text { Lanes } \\
\text { (Participants) }\end{array}$} & \multirow{3}{*}{$\frac{1}{2}$} & \multirow{3}{*}{$\begin{array}{l}\text { Responsible (person } \\
\text { or department) for } \\
\text { task execution and } \\
\text { process activities. }\end{array}$} & Player & $\begin{array}{l}\text { Police station (Policeman - from } \\
\text { narrative) }\end{array}$ \\
\hline & & & Characters & $\begin{array}{l}\text { Police station (Policeman - } \\
\text { narrative) and Citizen (Mother - } \\
\text { Narrative) }\end{array}$ \\
\hline & & & $\begin{array}{l}\text { Places - } \\
\text { Game } \\
\text { World }\end{array}$ & Police Station (DDPA) \\
\hline Initial Events & & $\begin{array}{l}\text { Event that starts a } \\
\text { process or part of a } \\
\text { process. }\end{array}$ & $\begin{array}{l}\text { Plot: Initial } \\
\text { Event }\end{array}$ & Missing person are reported \\
\hline \multirow{2}{*}{ Final Events } & & \multirow{2}{*}{$\begin{array}{l}\text { Events that finish a } \\
\text { process or part of a } \\
\text { process. }\end{array}$} & $\begin{array}{l}\text { Plot: } \\
\text { Solutions }\end{array}$ & $\mathrm{RO}$ (occurrence registry) is sent \\
\hline & & & Plot: Fails & Answer closed \\
\hline $\begin{array}{l}\text { Gateways } \\
\text { (Condition) }\end{array}$ & & $\begin{array}{l}\text { Controls the flow of } \\
\text { task execution, } \\
\text { defines a sequence in } \\
\text { a exclusive way. }\end{array}$ & Rules & $\begin{array}{l}\text { If }[\text { Case Analysis] }==[\text { Missing } \\
\text { person] then [Collect information] } \\
\text { If [Case Analysis] }==[\text { Other case }] \\
\text { then [Record Weird Fact }]\end{array}$ \\
\hline \multirow{2}{*}{$\begin{array}{l}\text { Instances } \\
\text { (Process } \\
\text { Courses) } \\
\\
\text { *From the } \\
\text { process model } \\
\text { document }\end{array}$} & & \multirow{2}{*}{$\begin{array}{l}\text { Example of ordered } \\
\text { task succession. They } \\
\text { describe an example } \\
\text { of how the process is } \\
\text { performed. }\end{array}$} & Story & $\begin{array}{l}\text { The police must record a RO to } \\
\text { investigate the missing of a child } \\
\text { based on her mother's notification. }\end{array}$ \\
\hline & & & Narrative & $\begin{array}{l}\text { The mother goes to the DDPA and } \\
\text { notifies her child is missing. The } \\
\text { policeman gets all relevant } \\
\text { information he can in order to create } \\
\text { an occurrence registry (RO) to start } \\
\text { the missing person investigation. }\end{array}$ \\
\hline \multirow{2}{*}{$\begin{array}{l}\text { Activities (Task } \\
\text { and Sub- } \\
\text { process) }\end{array}$} & \multirow[t]{2}{*}{ Task } & \multirow{2}{*}{$\begin{array}{l}\text { Works or tasks to be } \\
\text { performed in the } \\
\text { process context. }\end{array}$} & Tasks & $\begin{array}{l}\text { Person Welcome, Record Weird } \\
\text { Fact, Close the case, Collect } \\
\text { information, Record RO, Send RO, } \\
\text { Case Analysis. }\end{array}$ \\
\hline & & & Feedback & $\begin{array}{l}\text { Information, resources, points, } \\
\text { answers, complaints }\end{array}$ \\
\hline \multirow[b]{2}{*}{$\begin{array}{l}\text { Flows } \\
\text { (sequences, } \\
\text { messages, } \\
\text { information) }\end{array}$} & & \multirow[b]{2}{*}{$\begin{array}{l}\text { Represents atemporal } \\
\text { order in which } \\
\text { actions happen. }\end{array}$} & Interaction & $\begin{array}{l}\text { Player and tasks (actions) } \\
\text { Player and items (to get, to use, to } \\
\text { access) }\end{array}$ \\
\hline & & & Rules & $\begin{array}{l}\text { Sequence: Evaluate case [not } \\
\text { missing] Record Weird Fact }>\text { Close } \\
\text { the case } \\
\text { Evaluate case [is missing] Collect } \\
\text { information }>\text { Record RO > Send } \\
\text { RO }\end{array}$ \\
\hline Resources & & & Items & ROWeb, Information, RO, Help \\
\hline
\end{tabular}




\begin{tabular}{|l|l|l|l|l|}
\hline & Goals & $\begin{array}{l}\text { Represents data, } \\
\text { systems, files, forms, } \\
\text { etc. }\end{array}$ & Feedback & $\begin{array}{l}\text { Get RO, Information, ROWeb } \\
\text { access }\end{array}$ \\
\hline $\begin{array}{l}\text { *From the } \\
\text { process model } \\
\text { document }\end{array}$ & $\begin{array}{l}\text { Goal and motivations } \\
\text { to perform the } \\
\text { process. }\end{array}$ & Goal & $\begin{array}{l}\text { Send the occurrence registry to } \\
\text { discover the child disappearance. }\end{array}$ \\
\hline
\end{tabular}

\subsection{Game Project}

The game project step was inspired by Schell's game design vision [10], which proposed four main game design elements: narrative, mechanics, technologies, and aesthetics. We also use the BPMN model, the element mapping and the context document, which are required inputs to the step.

The game design project step should be concerned with the game designer's creativity, preventing them from creating elements which significantly hurt the business process purpose. This step aims to create possible game views, in order to complete and improve the GDD, putting into place the game design creativity to make the game attractive, without missing business characteristics.

This step comprises the following activities: 1) Game audience definition: from the context document, it is possible to identify business process actors/users/clients, which may be considered as the game audience/players. 2) Game Theme: the game theme might be a consensus in the team and must be selected consciously because it should not hurt human values as religion, cultural thoughts, beliefs, and others. 3) Characters: characters in this kind of games should be related to process actors, and game designers can create their appearance, characteristics, and skills. 4) Narratives: the context document may also provide information to be used in narratives, such as process instances, difficulties, curiosities, values, etc. In narrative, the context document created in the first step is used to put information about the process as values or extra information in the game world. 5) Mechanics and Aesthetics: designers must think about user actions and their interaction with the scenario, game items, characters, considering and actions observing business process rules, interactions, resources, etc. 6) Technologies: game technologies must be defined, for instance, engines, colors, videos, and others.

\subsubsection{Desaparecidos - Game Project}

The game project of the Desaparecidos aimed at placing the player in the role of a police officer, who must perform the process correctly, allowing the player to experience the process used at DDPA. To make project considerations, designers used the mapping element sheet and the context document to improve the GDD obtained in the previous step. The objective in the Desaparecidos project was to use the documents to represent the business process in the game context, without neglecting the business process nature.

As target audience, the designers decided to design the game for players above age 15 . The idea was to motivate and engage children to know about the process and to spread information about it to family, friends, and neighborhood. As game theme, designers decide to place it in the contemporary time, and the game world to be the police station. The business process does not show characters, but considering all instances provided by DDPA, both characters and narratives were found for the game. The selected narrative was thought to pass to the player the process executor view through the drama of a mother when her son does not arrive at home after school (Figure 4). Designers considered this instance less painful than other presented situations such as accidents or death. Values such as ethics, discipline, hierarchy, commitment, human rights, transparency, focus on the citizen, discovered during the context study, were included. Based on the genre adventure, 
pag. 38

mechanics actions were thought, such as "to talk", "to decide", "to get", "to use", "to give", "to access", all of them based on process execution. Other aspects considered in the game as mechanics (failures) present feedbacks to player - for each right process action performed the user earns points and increases the time to solve the case. On the other hand, if player performs wrong actions, time is decreased and mother's complaints are shown on the screen. Lastly, for technology, the designers used the RPG Maker to quickly create the game. All this information was recorded in the Game Design Document, and this document was sent to the development team.

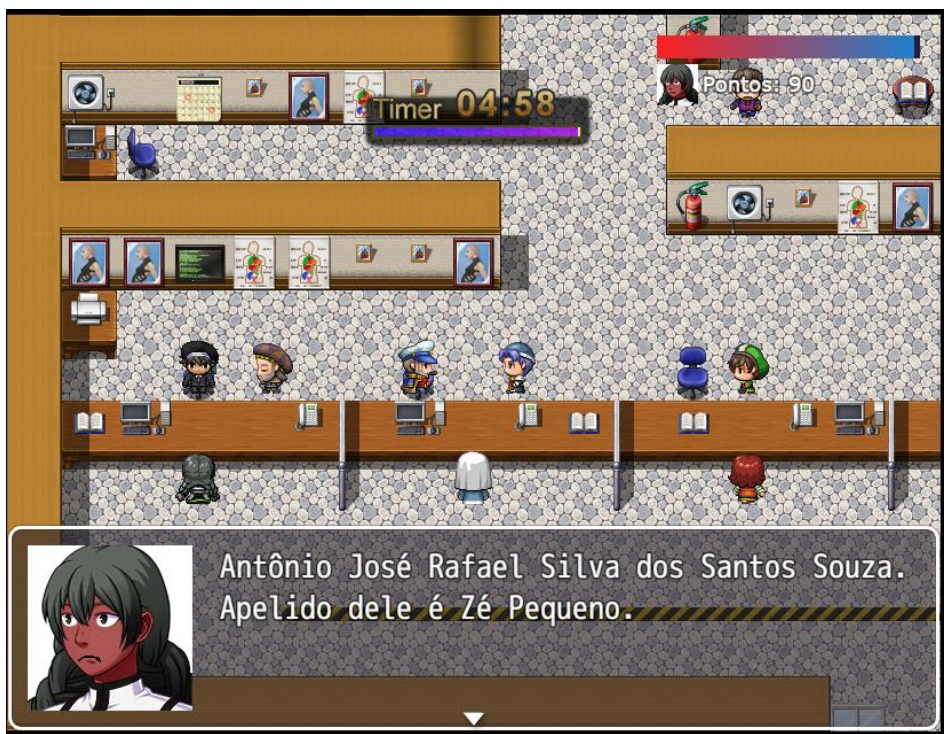

Figure 4. The player (police officer) listening to the mother's case narrative.

\subsection{Prototyping / Development}

The development or prototyping step comprises game coding. As input, it receives the game design document, which serves as a software requirement document. The goal of this step is building the digital game considering all requirements defined by the game design team and software game engines. A result of this step is game prototype (or version) which can be evaluated by game designers, process owners, and process users.

In the case of the Desaparecidos, the game coding was made by one programmer with a little experience in RPG Maker. The first game version had expended 2 months to be launched, and after evaluation, a new version was released.

\subsection{Evaluation}

The first evaluation consists of team evaluation which comprises prototype or game evaluation according to the GDD, and, as a result, an evaluation report. The team is responsible for checking whether all requirements were developed in the game. Furthermore, the game designer plays the game and evidences whether the ludic elements are balanced with business process elements. The first version of the game prototype usually comprises boring games, where the win and lose criteria are not well defined. In these cases, it is necessary to go back to the game project step in order to improve the game design.

The second evaluation comprises game evaluation with process actors using the process model and documentations, that is, with those within the organization who perform process activities. This step is necessary because these people have the knowledge of how the process is performed. Process executors should be able to recognize their organizational context in the game, in addition to organizational situations, environment, rules, goals, artifacts, and other organizational aspects involved in process execution. This evaluation 
step requires the use of the context document generated by the context study step, from which the game design team creates a checklist of the main organizational issues to be checked. Based on this checklist, the process actor plays the game and ascertains features presented or not during gameplay. If there are needs to fix in the game or to improve it, the evaluation report is sent back to the game design team, and a new game project step should be performed.

The last evaluation, with the target audience, aims at evaluating whether the game shows a comprehensive process to external users/clients. For this purpose, some evaluation methods have been found in the literature, for instance, the Serious Games Design Assessment Framework [43], EGameFlow [44] or the MEEGA+ model [45]. These have in common scales to measure distinct aspects of the game such as gameplay experience and the learning perception by the player. The PYP considers the above evaluation aspect and a third aspect, which is the process context.

Gameplay experience may be evaluated using gameflow aspects (usability, reliability, challenge, social interaction, satisfaction, focus, relevance, goal clarity, feedback, and fun); learning perception could use models as Bloom's taxonomy and learning objects in the form of evaluation scales; and process context could be considered to evaluate organizational and process contexts according to user perception, acquired in the context study step.

At the end of the evaluation, it is possible to treat the results statistically, thereby creating a report. In case the game receives a bad evaluation, this report is sent to the game design team, for a new game project step to be carried out.

\subsection{Desaparecidos - Evaluation}

In the first evaluation of the Desaparecidos, the game was considered very boring and deterministic, and more failure situations were introduced to make the game more challenging. Therefore, performing process model mapping for the game design element doesn't guarantee a challenging and immersive game.

As evaluations with process actors, the game was presented to process executors, mainly the police department officers, who were asked to play the game and check whether the game represents the process. Evaluation followed a checklist created with the context document information, with process rules, tasks, and other information such as police environment, characters, and situations that should be present in the game. Also, the business process model was delivered to process actors for these to follow the process flow in the game world, and to analyses whether it was correct. The DDPA officers played the game and considered it a good portrait of the missing person discovery service.

User evaluation is described in section 6 through a case study.

\subsection{Evaluation}

The last step of the PYP comprises game publishing and delivery. This means that the purpose is to join all game resources into a simple package and deliver it in some game platform to the players in a playable version, including game help.

The Desaparecidos can be played from the Google Play Store downloads or by the link: http://tadeuclasse.com.br/games/desaparecidos.

\section{Other Game Examples}

The PYP method was used in the design of other games, mainly for designing games from public service processes in the Brazilian context. For instance, the game "Cartão SUS Adventure" (SUS Card Adventure, in English) (Figure 5) is an adventure game designed to explain to Brazilian citizens the process for obtaining the public health insurance card. The player plays the game by going through different process steps, where documentation and 
pag. 40

pieces of information are obtained as resources, and interacting with characters which represent process actors. The game also explores different values concerning the process citizenship, respect, life quality and ethics.

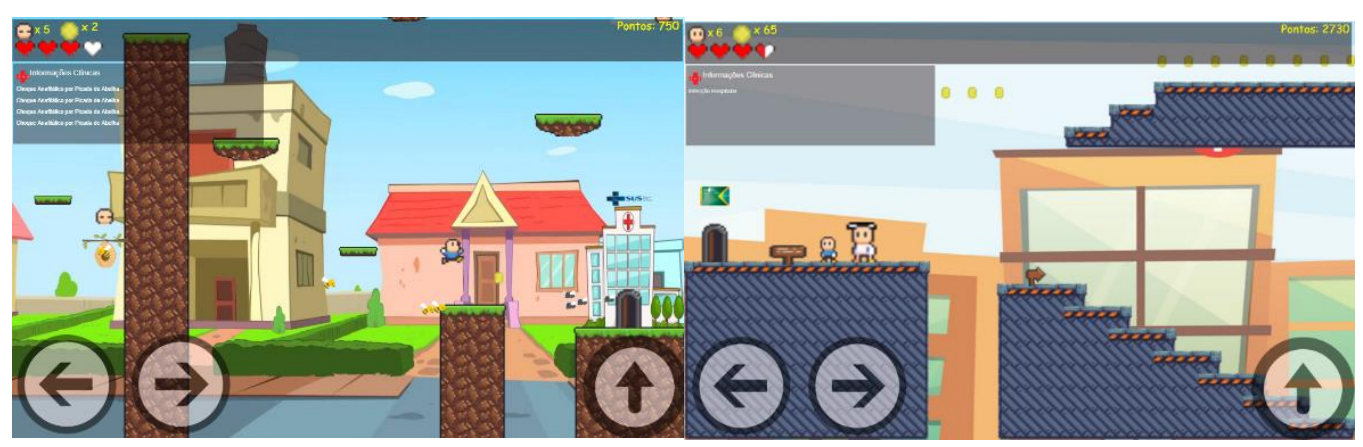

Figure 5. SUS Card Adventure

"The ProUni Game" (Figure 6) is an RPG/Adventure game based on the ProUni application process in Brazil. The ProUni is a federal government education program to grant scholarships in private universities. The PYP was used to create a game including values, tasks and the context in order for the players to learn how to acquire that service.

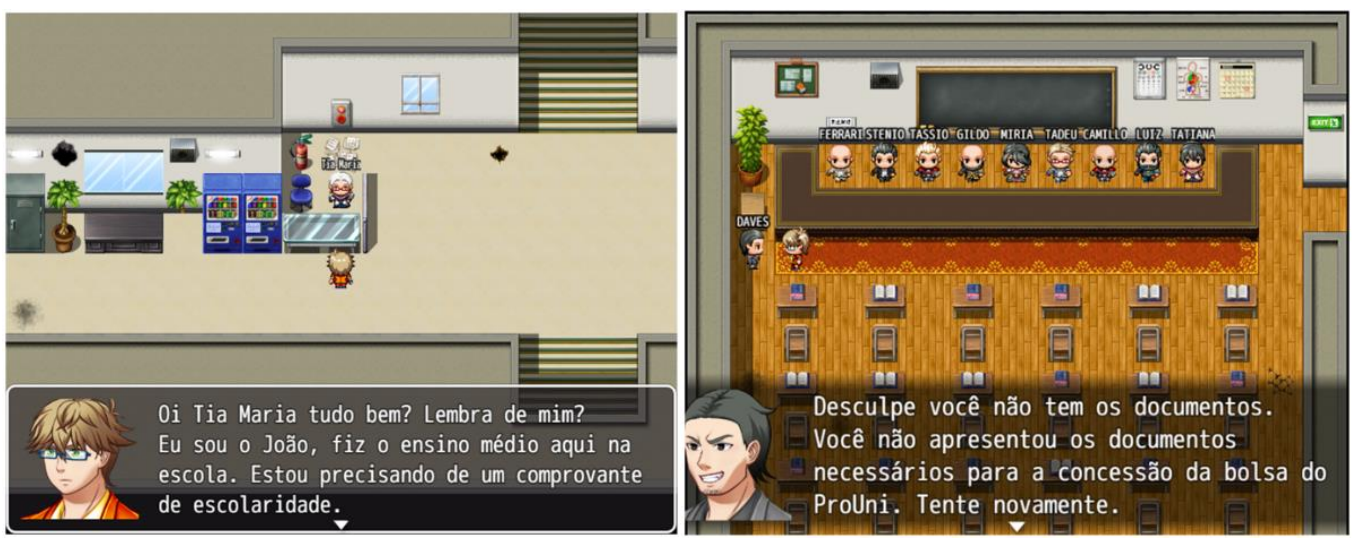

Figure 6. The ProUni Game.

Applying for a passport document is considered a complex process by many Brazilian citizens. The game "Passaporte Intergalático" (Intergalactic Passport, in English) (Figure 7) was designed to help Brazilian citizens to better understand the details of this process.

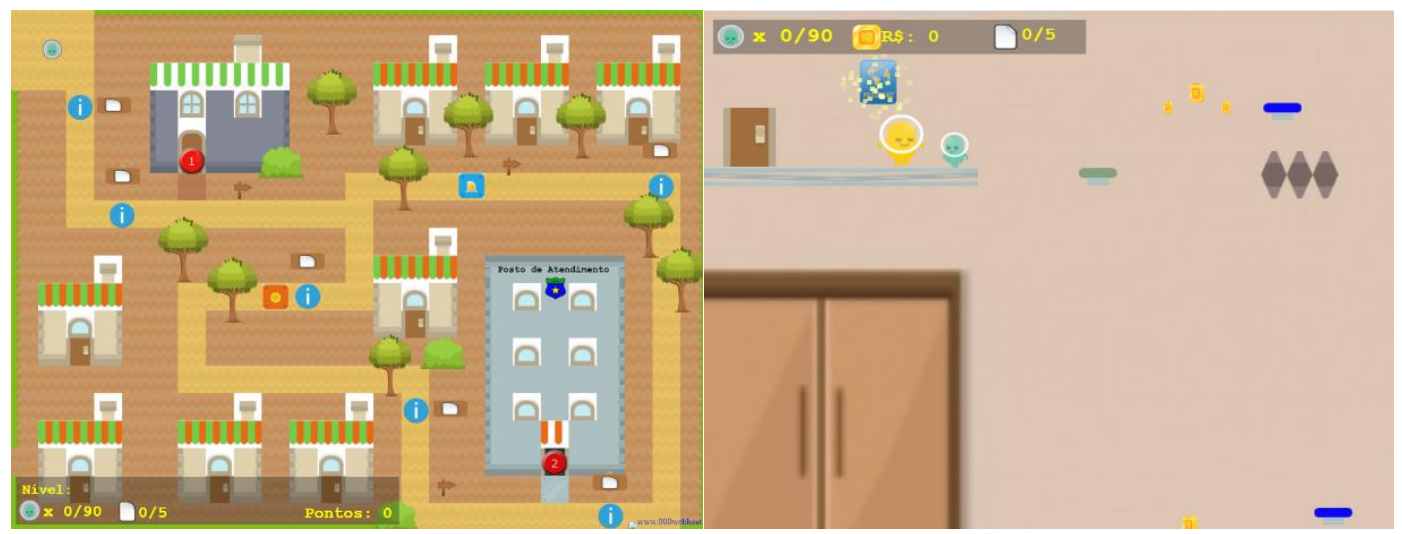

Figure 7. Intergalactic Passport.

All the games designed using the PYP have the characteristic of providing an imaginary and magic game world to players together with keeping real process particularities. 


\section{User Evaluation - Case Study}

User evaluation of the Desaparecidos was made with users in an experimental context, but considering real process users, i.e., Rio de Janeiro citizens. For this evaluation, we used a simplified version of the EGameFlow method [44] and it was mixed with Bloom's taxonomy. EGameFlow comprises criteria such as measuring the quality of the SG in terms of gameflow. Bloom's taxonomy was used to detail the evaluation of players' knowledge gain because in the EGameFlow, the knowledge is computed only by the player's perception after the game use, it isn't checked before.

\subsection{Objectives and Scope}

The objectives of the case study are presented according to the Goal Question Metric paradigm [46]:

O1) Analyse the game Desaparecidos, with the purpose of evaluating the game quality criteria; with the respect of players' quality perception; from the point of view of Brazilian citizens; in the context of the missing person discovery process.

O2) Analyse the game Desaparecidos; with the purpose of evaluating the process understanding; with the respect of players' knowledge; from the point of view of Brazilian citizens; in the context of the missing person discovery process.

\subsection{Participants}

This study was performed with 83 participants. The participants were selected by convenience, being students and teachers of a Brazilian school. All participants did not receive any reward for participating in the study.

\subsection{Study Planning}

The experiment considered two steps, pre and post-test. In the pre-test, users answered questions about the missing person discovery service, in order to record their knowledge about the process and to check the gameplay perception (10 minutes). Afterwards, they played the Desaparecidos for one hour. The post-test comprised EGameFlow questions about the game context in each gameflow using criteria using Likert scale from 0 (I do not agree at all) to 4 (I agree completely). All the questions of EGameFlow were translated into Portuguese.

EGameFlow does not measure learning goals. Finally, they answered the same pre-test questionnaire, which allowed us to check whether knowledge had been gained. [28]. To compute the knowledge level of each participant, Bloom's taxonomy competencies levels ("Remember", "Understand" and "Apply") were used, codified in a Likert scale. Results were computed by the expression: Knowledge $=[($ Remember $* 1)+($ Understand $* 2)+$ $($ Apply* 3)] / 6 (weighted average).

The threats of validity of the study are presented by the Table 3 . 
Table 3. Threat of Validity

Threat Threat treatment

Power of statistical method analysis, due to $\quad$ Specific statistical methods were used according to each existence of many statistical methods and ways situation, scale, variable, interval, normality behavior, etc. to use.

Participant's previous knowledge (someone could know something about the business process used).

After the first questionnaire, it was possible to identify and Lack of participant training. separate participants according to their knowledge about the service.

Lack of participant training.

maximum time stipulated was 1 hour and 30 minutes. The study was explained to all, together with its tools and

\begin{tabular}{|l|l|}
\hline Researcher expectations. & The researcher did not have contact with the participants \\
\hline
\end{tabular} in the study.

\begin{tabular}{ll|l} 
Exchange of information among participants. & To decrease the risk the study was performed on a single
\end{tabular} day, separating the participants in computers in a same room.

Affinity with researcher.

The study was applied by another people without affinity with the participants.

Data analysis was conducted using the software R Statistics (3.2.2), with the value of $5 \%$ defined as significance level (alpha $=0.05)$.

\subsection{Results}

\subsubsection{O1 - Game Quality Criteria}

Based on the EGameFlow criteria, users perceived Desaparecidos as a good in general, allowing player control, autonomy and concentration, providing feedback with clear goals (Figure 8 - Table 4 ). The evaluation shows that the mean of quality reached 2.73 points (sd $=-+1.17)$. 


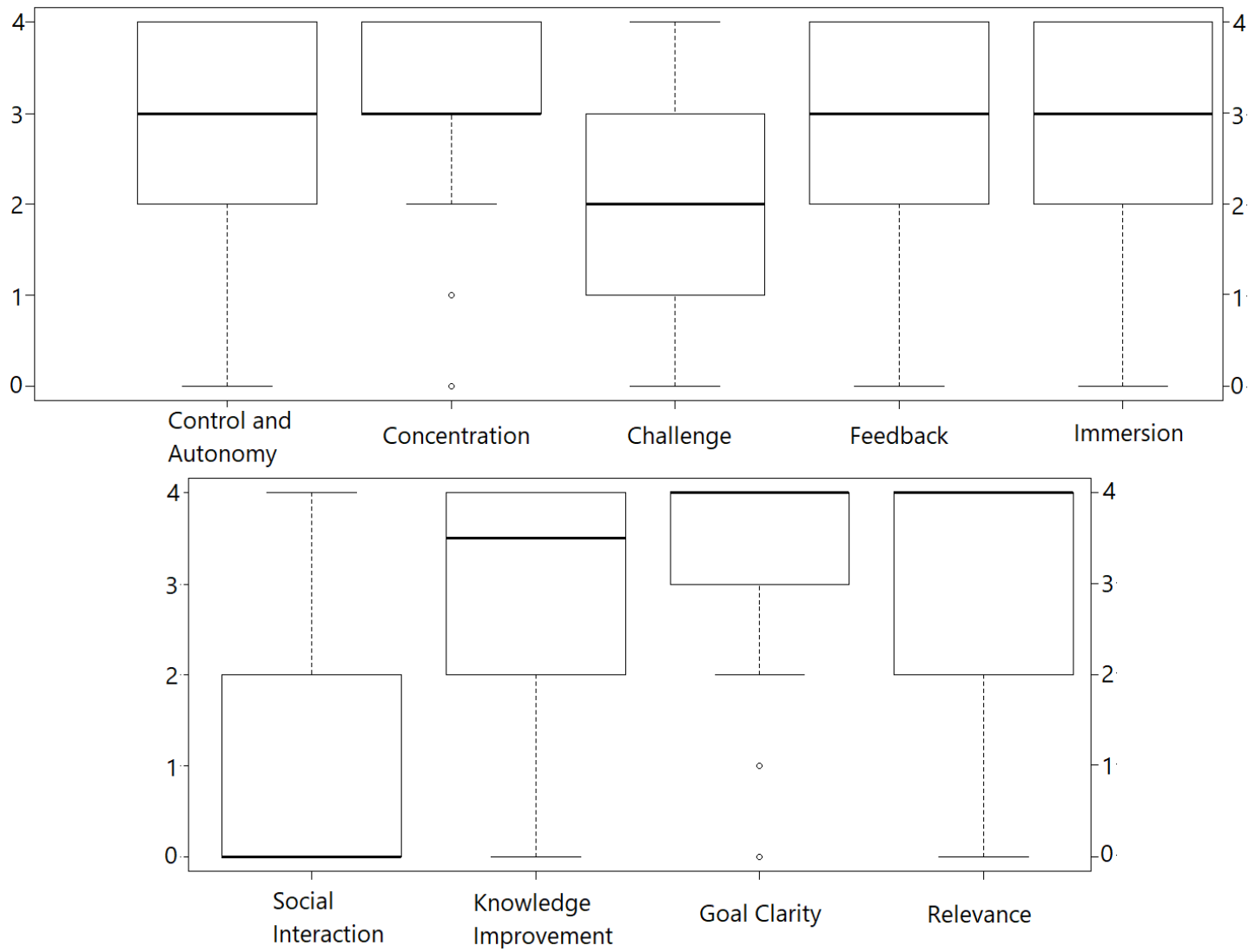

Figure 8. Game Quality Results ( $x=$ quality criteria; $y=$ points in Likert's scale)

Table 4. Descriptive Statistics To Game Quality

\begin{tabular}{|l|r|r|r|}
\hline Quality Criteria & \multicolumn{1}{c}{ Mean } & \multicolumn{1}{c|}{ Med } & Sd \\
\hline Concentration & 3.15 & 3.00 & 0.96 \\
\hline Goal Clarity & 3.30 & 4.00 & 0.96 \\
\hline Feedback & 3.04 & 3.00 & 1.09 \\
\hline Challenges & 2.03 & 2.00 & 1.39 \\
\hline Autonomy and Control & 2.83 & 3.00 & 1.17 \\
\hline Immersion & 2.90 & 3.00 & 1.26 \\
\hline Social Interaction & 1.15 & 0.00 & 1.40 \\
\hline Relevance & 3.03 & 4.00 & 1.21 \\
\hline Knowledge Improvement & 3.12 & 3.50 & 1.06 \\
\hline Total Quality (Mean) & $\mathbf{2 . 7 3}$ & $\mathbf{2 . 8 3}$ & $\mathbf{1 . 1 7}$ \\
\hline
\end{tabular}


pag. 44

\subsubsection{O2 - Knowledge Increase}

We calculated knowledge increase for each business process activity presented in the process model, comparing pre- and the post-test answers, (Figure 9). It was calculated by summing up the players' perceptions about what they were able to remember, understand or apply about the process. The results vary between 0 points (no knowledge) and 4 points (maximum knowledge).

The Shapiro-Wilk test was used to check whether the results of F1 (pre-test) and F2 (post-test) followed a normal distribution. On Table 4 it is possible to see that none of them followed the Normality test, none of them presented p-value less (or close) than 0.05 (alpha 5\%). Therefore, the Wilcoxon test was used. From the Wilcoxon Test in Table 4, it is possible to see that all p-values are below 0.05 points. Thus, it is possible to affirm with at least $95 \%$ of certainty that the game supported the business process learning by the players. Using the Vargha-Delaney Test to calculate effect size (Table 4), it is possible to identify that, in the worst case, $89.6 \%$ of the participants had their knowledge about the process increased, against $10.4 \%$ which did not.

Table 5. Inferential Statistics To Learning Increase

\begin{tabular}{|r|r|r|r|}
\hline Phases Shapiro-Wilk & \multicolumn{1}{c}{ Wilcoxon } & Vargha Delaney (A12) \\
F1 - Occurrence Creation & $1.752 \mathrm{e}-11$ & \multirow{2}{*}{$2.2 \mathrm{E}-16$} & 0.068442 \\
F2 - Occurrence Creation & 0.000134 & & 0.931557 \\
F1 - Collect Information & $1.137 \mathrm{e}-09$ & \multirow{2}{*}{$4.0 \mathrm{E}-20$} & 0.086443 \\
F2 - Collect Information & 0.02204 & & 0.913557 \\
\hline F1 - Record RO & $1.263-\mathrm{e} 08$ & \multirow{2}{*}{$1.2 \mathrm{E}-18$} & 0.103934 \\
\cline { 2 - 2 } F2 - Record RO & 0.000517 & & 0.896066 \\
\hline F1 - Send RO & $2,746 \mathrm{e}-12$ & \multirow{2}{*}{$4.18 \mathrm{E}-22$} & 0.080708 \\
F2 - Send RO & 0.002082 & & 0.919291 \\
\hline
\end{tabular}



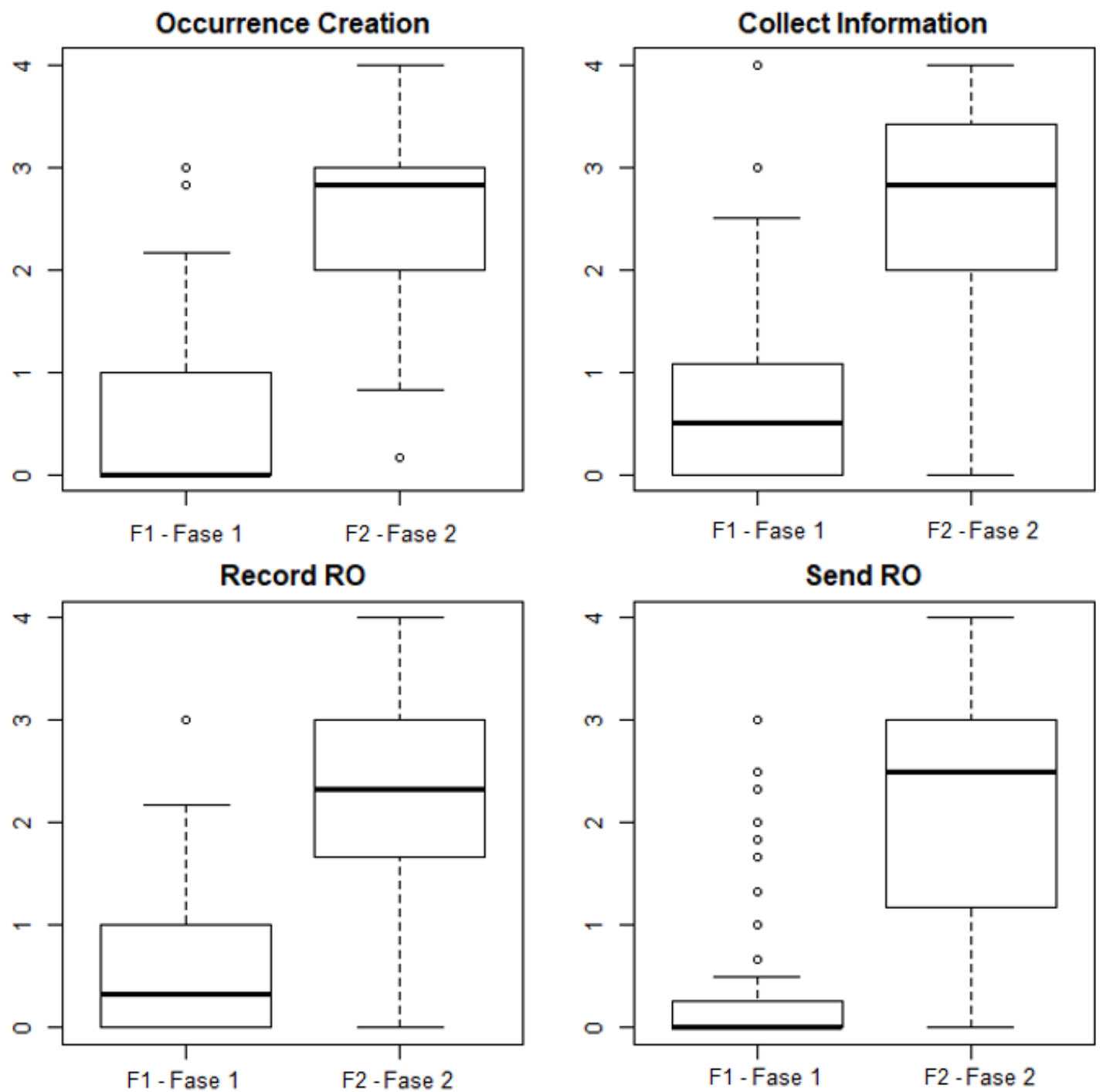

Figure 9. Comparison of process steps between pre-test (Fase 1) and post-test (Fase 2).

Therefore, the results show evidence of the improvement of knowledge from Fase 1 to Fase 2. Although the evaluation values are good, it was based only on the players' knowledge perception yet. We think necessary to find a new way to evaluate knowledge, based on a concrete evaluation of terms, concepts, and reasons for use.

\section{Limitations}

Concerning limitations, the method is restricted to process models based on BPMN model, bringing out the opportunity to study other business process modeling languages as input. In addition, the mapping element step provided by the method is focused only on Adventure games. Due to the business process nature - sequence of steps/activities performed by actors according to rules, adventure games are a natural game genre to think about. However, we believe that there is a good opportunity to define conceptual mapping to other game genres as well, giving the designer different possibilities to explore game design.

The game evaluation step may also be improved so as to consider other issues beyond process activities and game quality, such as process context, organizational values, etc. Another issue concerning the evaluation step is that it allows us to measure immediate 
pag. 46

knowledge obtained by the player after gameplay, but not to understand whether this knowledge will be maintained in the future.

Our goal from the game design method approach is not to create software sources, assets, sprites in an automatic way. We understand that each serious game is unique, and they need to be designed carefully by designers, programmers and artists. Our method is focused on dealing with the interdisciplinarity between BPM and game design. To design serious games, knowledge of the domain (process) experts is necessary. The proposed method decreases the gap between BPM and game design especially through the conceptual mapping step.

\section{Conclusions}

This article presented a game design method to build business process-based digital games, helping organizations innovate using games as an interface with process actors and process clients. The method is interactive and guides the designer (game designers or business analysts) to understand the business process, mapping the business process model to a game context and elements, as well as to evaluate the game aspects (balance, process execution, quality and learning).

Different from other serious games design proposals, our approach is focused on business process models as a source of the game design information that allows us to systematize a number of steps of the design process. These systematic steps support the mapping of business process elements to game design elements, in a document sheet, providing a first view of a GDD. The business process models are used in all steps, providing information and resources to game design and evaluations.

The game design method was described and demonstrated in the article through the Desaparecidos Game case study. An evidence from the evaluation steps is the balance among process elements and game elements, as the game represents the business process correctly. The players agreed with the quality of the game and the understanding of the process was increased.

Returning to the question whether is possible to design digital games based on a business process which helps players understand and learn about the underlying process, our studies indicates so, as the method supported the game design process to create serious games grounded on the business process. Therefore, our game design method contributes to the game design engineering.

As future work, we propose studying and creating specific game evaluation scales, measuring business process-based digital games generated by the method, involving aspects such as game quality, player learning, process values and relevance.

In the evaluation of the Desaparecidos game, a low level of social interaction was perceived by payers. In Social BPM, collaboration is an important aspect to support the communication of the actors and process improvement. Therefore, it must be considered in the design of business process-based digital in future work, maybe through design of multiplayer games or collaboration mechanics.

The design of more games using the PYP method is also in the research plan. It is possible to improve the game design method, as for instance, traceability among game design outcomes generated could help designers to trace game fails; and game versioning by a unique design tool, as well as thinking about stages of the game (alpha, beta, release), which are important to determine the game release version for the audiences. 


\section{Acknowledgements}

Renata Araujo is supported by the Brazilian National Council for Scientific and Technological Development (CNPq) under grant 05060/2016-3. Sean Siqueira is supported under grant 312039/2015-8.

\section{References}

[1] L. Bennis, \& S. Benhlima, "Comparative study of the process model of Serious Game Design through the generic model DICE”, In Advances in Intelligent Systems and Computing, 47-52, 2015

[2] T. Susi, M. Johannesson, P. Backlund, "Serious Games: An Overview", In Sweden: Institutionen För Kommunikation Och Information, pp. 28, 2007.

[3] A. De Gloria, F. Bellotti, R. Berta and L. Elisa, "Serious Games for education and training". In International Journal of Serious Games, Vol. 1, Nr. 1, 2014. https://doi.org/10.17083/ijsg.v1i1.11.

[4] D. Michael, S. Chen, "Serious Games - Games that Educate, Train, and Inform", Thomson Course Technology PTR, Boston, 2005.

[5] F. Laamarti, M. Eid, A.E. Saddik, "An overview of serious games". In International Journal of Computer Games Technology, 2014. https://doi.org/10.1155/2014/358152

[6] M. Dumas, M. La Rosa : Mendling, J.; Reijers, H.A. "Fundamentals of business process management". Berlin: Springer, 2013. https://doi.org/10.1007/978-3-642-33143-5

[7] K. Peffers, T.Tuunanen, M. A. Rothenberger, \& Chatterjee, S. "A design science research methodology for information systems research". In Journal of management information systems, 24(3), 45-77, 2007. https://doi.org/10.2753/MIS0742-1222240302

[8] D. Volk, "How to embed a game engineering course into a computer science curriculum". In: Proceedings of the 2008 Conference on Future Play: Research, Play, Share. ACM, pp. 192-195, 2008. https://doi.org/10.1145/1496984.1497019

[9] K. Salen, E. Zimmerman, "Rules of play: Game design fundamentals". Cambridge, Mass.: MIT Press, 2003.

[10] J. Schell, "The Art of Game Design A Book of Lenses", Burlington. USA: Morgan Kaufmann Publishers \& Elsevier, 2009.

[11]R.A. Santos; Góes, V.A., L.F. Almeida, "Metodologia OriGame: um processo de desenvolvimento de jogos" (English title: OriGame methodology: a game design process). In: Simpósio Brasileiro de Games e Entretenimento Digital (SBGames), 2012. (In Portuguese).

[12]M. E. Paschali, N. Bafatakis, A. Ampatzoglou, A. Chatzigeorgiou, \& L. Stamelos, "Toolassisted Game Scenario Representation Through Flow Charts". In ENASE, pp. 223-232, 2018. https://doi.org/10.5220/0006681402230232

[13]C. Keith, "Agile game development with Scrum”. Pearson Education, 2010.

[14]P.H.F. Ng, "Introducing the practices for adopting the constructivist teaching in game engineering". In: Global Engineering Education Conference (EDUCON), 2017 IEEE, pp. 16361643, 2017. https://doi.org/10.1109/EDUCON.2017.7943068

[15]R. Da Conceicao, C. Locke, K. Cooper, \& C.S. Longstreet,. "Semi-automated serious educational game generation: A component-based game engineering approach". In: Computer Games: AI, Animation, Mobile, Interactive Multimedia, Educational \& Serious Games (CGAMES), 2013 18th International Conference on, pp. 222-227, 2013.

[16] W.M.P.Van Der Aalst, A. Ter Hofstede, M. Weske, "Business process management: A survey", In International conference on business process management, pp. 1-12, 2003.

[17] A. Sharp, P. McDermott, "Workflow Modeling: Tools for Process Improvement and Applications Development". Artech House, 2 ed., 2008.

[18]R.S. Aguilar-Saven, "Business process modelling: Review and framework", In International Journal of production economics, v.90(2), pp. 129-149, 2004. https://doi.org/10.1016/S09255273(03)00102-6

[19] N. Pflanzl, "Gameful Business Process Modeling." EMISA. 2016.

[20]F. Schönthaler, G. Vossen, A. Oberweis, T. Karle, "Business Processes for Business Communities: modeling languages, methods, tools", Springer, German, 2012. 
pag. 48

[21]M. Brambilla, P. Fraternali and C.K. Vaca Ruiz, "Combining social web and BPM for improving enterprise performances", In Proceedings of the 21 st international conference companion on World Wide Web-WWW '12 Companion, pp. 223, 2012. https://doi.org/10.1145/2187980.2188014

[22] C. Richardson, "Social BPM: Work, Planning and Collaborations Under the Impact of Social Technology". Future Strategies, Florida, 2011.

[23] N. Pflanzl, and G. Vossen, "Human-Oriented Challenges of Social BPM: An Overview", In Proceedings of the 5th International Workshop on Enterprise Modelling and Information Systems Architectures, pp. 163-176, 2013.

[24] S.E.A Erol , “Combining BPM and Social Software: Contradiction or Chance?”, In Journal of Software Maintenance and Evolution: Research and Practice, 22(6-7), pp. 449-476, 2010. https://doi.org/10.1002/smr.460

[25] Rangiha, Mohammad Ehson and Bill Karakostas. "Towards a meta-model for goal-based social BPM." International Conference on Business Process Management. Springer, Cham, 2013.

[26] K. D. Swenson, "Social BPM: work, planning and collaboration under the impact of social technology". Future Strategies Inc., 2011.

[27] W.S. Afandi, W.S. Afandi, "Social Business Process Modeling: Opportunities and Challenges", Hawaii University International Conferences, 2016

[28] T. Classe, R.M. Araujo, G.B. Xexéo, "Jogos Digitais Baseados em Processos de Prestação de Serviços Públicos: Um Estudo Exploratório" (English title: Digital Games Based on Process of Public Services Delivery), International Journal of Game Studies (Ludica), v.2(2), pp. 26-56, 2018. (In Portuguese).

[29] P. Siriaraya, V. Visch, A. Varmeeren, M. Bas, "A cookbook method for Persuasive Game Design". In: International Journal of Serious Games (IJSG), v.5(1), pp. 37-71, 2018. https://doi.org/10.17083/ijsg.v5i1.159

[30] W. Brian, "The design, play, and experience framework". In: Handbook of research on effective electronic gaming in education, IGI Global, v.3, pp. 1010-1024, 2008.

[31] S. Dzgoeva, "Development of a Gamification Design Method for a Business Process Modeling Tool". Master Thesis. Westfälische Wilhelms-Universität Münster, 2016

[32] H. Kelly, K. Howell, E. Glinert, L. Holding, C. Swain, A. Burrowbridge, M. Roper. "How to Build Serious Games". In: Communications of the ACM, v.50(7), pp.45-49, 2007. https://doi.org/10.1145/1272516.1272538

[33] T. R. Classe, R. Araujo, “Jogos Digitais Para Participação Cidadã em Processos de Prestação de Serviços Públicos" (English title: Digital Games to the Citizen Participation in Processes of Public Services), In Workshop de Teses e Dissertações SBSI (WTDSI), 2016. (In Portuguese).

[34] T. Classe, R.M. Araujo, G.B. Xexéo, "Process Model Game Design: Uma Ferramenta para Apoio a Sistematização de Design de Jogos Digitais Baseados em Processos de Negócio" (English title: Process Model Game Design: A Tool to Support the Systematization of Digital Games Based on Business Process). In: XVII Simpósio Brasileiro de Jogos e Entretenimento Digital (SBGames 2018), 2018.

[35] T. Classe, R. Araujo, "Gamificação Para Participação Social em Processos de Prestação de Serviços Públicos: Mapeamento Sistemático" (English title: Gamification to Social Participation in Process of Public Services: Systematic Mapping). In Simpósio Brasileiro de Sistemas Colaborativos (SBSC), Salvador, 2015. (In Portuguese).

[36] J. Solís-Martínez, J.P. Espada, N. García-Menéndez, B. C. P.G-Bustelo, \& J. M. C. Lovelle, "VGPM: Using Business Process Modeling For Videogame Modeling And Code Generation In Multiple Platforms". In Computer Standards \& Interfaces, 42, 42-52, 2015. https://doi.org/10.1016/j.csi.2015.04.009

[37] N. Pflanzl, T. Classe, R. Araujo, G.Vossen, "Designing Serious Games for Citizen Engagement in Public Service Processes". In International Workshop Series on Business Process Management and Social Software, Rio de Janeiro, 2016.

[38] T.M. Classe,R.M. Araujo, G.B. Xexéo, “De Processos de Negócio para Jogos Digitais: Uma Proposta de Mapeamento" (English title: From Business Process to Digital Games: A Mapping Proposal), In Simpósio Brasileiro de Sistemas de Informação (SBSI), 2018. (In Portuguese).

[39] T. Classe, R. Araujo, G.B. Xexéo, “Combining Business Process Models into Digital Games Design: A Literature Review”, In RelateDIA - Relatórios Técnicos do Departamento de Informática Aplicada da UNIRIO, 2018.

[40] A.O. Rodrigues, R. Kronig, "O Uso do BPM no Desenvolvimento de Jogos" (English title:The use BPM in Game Development). In FaSCi-Tech, 1(3), 2010. 
[41]F. Grandin, H. Coelho, "Rio tem 33 mil desaparecidos em 15 anos; Zona Oeste e Bonsucesso concentram casos". (Rio has 33 thousand of missing people in 15 years)Portal de Notícias G1, 2017. Accessed at June 6th, 2018. (In Portuguese).

[42] A.S. Zahari, L.A. Rahin, M. Mehat, “A review of modelling languages for adventure educational games". In International Conference on Computer and Information Sciences (ICCOINS), pp. 495-500, 2016. https://doi.org/10.1109/ICCOINS.2016.7783265

[43] K. Mitgutsch, N. Alvarado, "Purposeful by Design? A Serious Game Design Assessment Framework". In: Proceedings of the International Conference on the foundations of digital games, pp. 121-128, 2012.

[44]F. Fu, R. Su, S. Yu, "EGameFlow: A scale to measure learners' enjoyment of e-learning games". In: Computer and Education, v. 52(1), pp. 101-112, 2009. https://doi.org/10.1016/j.compedu.2008.07.004

[45] G. Petri, C. Gresse, A.F. von Wangenheim, A.F. Borgatto, "MEEGA+, Systematic Model to Evaluate Educational Games". In: Lee N. (eds) Encyclopedia of Computer Graphics and Games. Springer, 2018. https://doi.org/10.1007/978-3-319-08234-9_214-1

[46] V. Basili, Software Modeling and Measurement: The Goal/Question/Metric paradigm, 1992. 